\title{
Fatal Outcome of a Young Woman with Papillary Thyroid Carcinoma and Graves' Disease: Possible Implication of "Cross-Signalling" Mechanism
}

apresentação de caso

\author{
GRACIELA A. DE CRoss \\ Horacio SUAREZ \\ FABIÁN PITOIA \\ Daniel Moncet \\ María Vanegas \\ OsCAR D. BRUNO \\ Hugo NiepomniszCZE
}

Division of Endocrinology Hospital de Clínicas - University of Buenos Aires. Buenos Aires,

Argentina (GAC, FP, DM, MV, $\mathrm{ODB}, \mathrm{HN})$; Laboratoire d'Instabilite Genetique et Cancer (UPR 2169), Institut de Recherches sur le Cancer, C.N.R.S.-IFR 89, Villejuif Cedex, France (HS)

Recebido em 8/5/2008 Aceito em 19/8/2008

\author{
ABSTRACT
}

A 29 yrs-old patient was referred to our hospital due to generalized convulsions. She had hyperthyroidism treated with methimazole. Her MRI showed 4 metastatic lesions in the brain. She had a goiter with a "cold" nodule and a palpable ipsilateral lymph node. The FNAB disclosed a papillary thyroid carcinoma. Under $5 \mathrm{mg}$ of MMI treatment, she had a subclinical hyperthyroidism and TRAb were $47.8 \%$ (n.v. < 10\%). The CT scan also showed lung metastasis. She underwent a total thyroidectomy with a modified neck dissection and she received an accumulated radioiodine dose of $700 \mathrm{mCi}$ during the following two years. She died from the consequences of multiple metastatic lesions. Studies were performed in DNA extracted from paraffin-embedded tissue from the tumor, the metastatic lymph node and the non-tumoral thyroid. The genetic analysis of tumoral DNA revealed point mutations in two different genes: the wild type CAA at codon 61 of $N$-RAS mutated to CAT, replacing glycine by histidine $(\mathrm{G} 61 \mathrm{H})$ and the normal GCC sequence at codon 623 of the TSHR gene was replaced by TCC, changing the alanine by serine (A623S). In the non-tumoral tissue no mutations were found. In vitro studies showed a constitutive activation of the TSHR. It is very probable that this activating mutation of the TSHR is unable to reach the end point of the PKA cascade in the tumoral tissue. One possibility that could explain this is the presence of a cross-signaling mechanism generating a deviation of the TSH receptor cascade to the more proliferative one involving the MAPKinase, giving perhaps a more aggressive behavior of this papillary thyroid cancer. (Arq Bras Endocrinol Metab 2008; 52/7:1194-1200)

Keywords: Thyroid, cancer; TSH; Receptor; Mutation; N-RAS; Graves

\section{RESUMO}

Desfecho Fatal de uma Paciente com Carcinoma Papilífero de Tiróide e Doença de Graves: Possível Implicação do Mecanismo de Sinalização Cruzada.

Paciente de 29 anos foi encaminhada ao Hospital de Clínicas por causa de convulsões generalizadas. Apresentava hipertiroidismo tratado com metimazol (MMI). A ressonância magnética mostrava quatro lesões metastáticas cerebrais. Possuía bócio com nódulo frio e linfonodo palpável ipsilateral. Usando $5 \mathrm{mg}$ de $\mathrm{MMI}$, a paciente apresentava hipertiroidismo subclínico e TRAb $=47,8 \%$ (normal $<10 \%$ ). A tomografia computadorizada também mostrava metástases pulmonares. A paciente foi submetida a tiroidectomia total com dissecção cervical modificada e recebeu dose acumulada de radioiodo de $700 \mathrm{mCi}$ durante o período de dois anos. Foi analisado o DNA extraído de tecido emblocado em parafina do tumor, do linfonodo metastático e de tecido tiroidiano não-tumoral. Foram encontradas mutações pontuais em dois genes: uma substituição do genótipo selvagem CAA no códon 61 de /N-RAS/ por CAT, substituindo a glicina pela histidina (G61H) e uma substituição da seqüência normal GCC no códon 623 do gene TSHR por TCC, trocando a alanina pela serina (A623S). Não foram encontradas mutações no tecido não-tumoral. Estudos in vitro mostraram ativação constitutiva de TSHR. Já que esta mutação ativadora de TSHR foi incapaz de atingir o final da cascata PKA no tecido tumoral, sugere-se que um mecanismo de cross-signaling possa explicar o desvio da cascata do receptor de TSH para outra mais proliferativa, envolvendo MAPKinase e levando ao comportamento mais agressivo deste câncer papilífero. (Arq Bras Endocrinol Metab 2008; 52/7:1194-1200)

Descritores: Câncer de tireóide; TSH, Receptor; Mutação; N-RAS; Doença de Graves 


\section{INTRODUCTION}

T hyroid tumors represent an appropriate model for the study of epithelial neoplastic transformation. Indeed, different types of tumors (benign adenomas, differentiated and anaplastic carcinomas) are well recognized, in vitro models which reproduce different degrees of neoplastic transformation are available and functional parameters (i.e. iodine uptake, hormone production, response to TSH stimulation) can be studied in vivo or in vitro. The roles of somatic mutations, gene rearrangement(s) and level of gene expression in carcinogenesis are now well established. Several techniques can be used to detect such genetic alterations in human tumors. The application of these techniques to thyroid tumors has focused particular attention on the role of point mutations activating (or inhibiting) the genes for the TSH receptor (TSHR), RAS, gsp, and p53. (1-9). Recently we have reported two different mutations, involving the TSHR and the $\mathrm{Ki}$-RAS genes in a follicular carcinoma presented as an entire AFTN (8).

We are now presenting the case of a patient with a past history of Graves' disease who developed an aggressive metastatic papillary thyroid carcinoma harboring two different mutations (TSHR and N-RAS) but showing a "cold" nodule at scintigraphy. Here we discuss the possibility of cross-signaling in the ethiopathogenesis and in the behavior of this neoplasia.

\section{PATIENT}

\section{Case report}

A 29 y.o. woman was referred to our Hospital due to generalized convulsions. The patient had a diagnosis of Graves' disease which was treated during 16 months with methimazole (MMI). The scintigraphy performed at diagnosis of the hyperthyroidism showed a $3 \mathrm{~cm}$ "cold" nodule localized in the right thyroid lobe (Figure 1). A palpable ipsilateral lymph node was discovered at routine neck examination. Central nervous MRI showed four metastatic lesions in the brain (Figure 2) and a CT scan showed nodular lung metastases. The FNAB disclosed a papillary thyroid carcinoma in both, the "cold" nodule and the palpable lymph node.

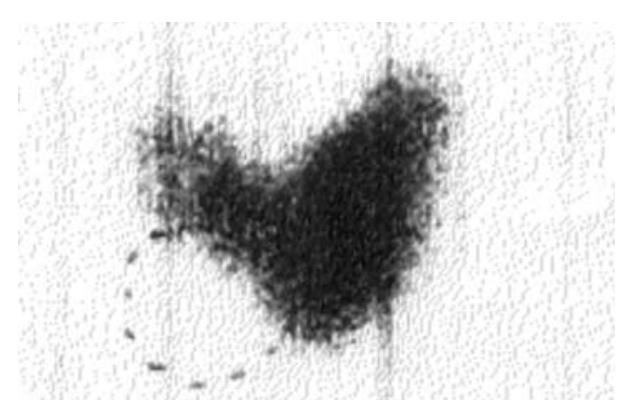

Figure $1 .{ }^{131}$ thyroid scintigraphy showing the presence of one "cold" area corresponding to the palpated right thyroid nodule associated to a high radioiodine uptake in the rest of the gland.

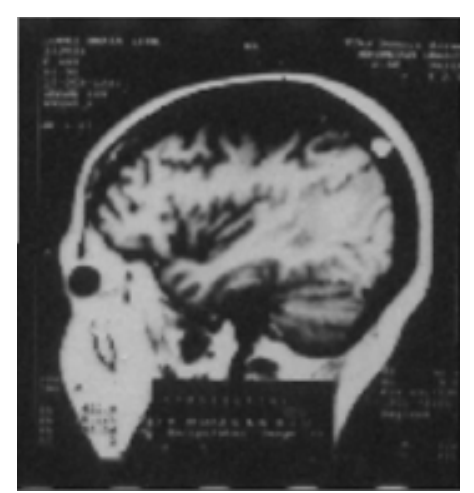

Figure 2. MRI showing a metastatic lesion in CNS.

While receiving $5 \mathrm{mg}$ MMI treatment, the thyroid profile was as follows: $\mathrm{T}_{3}=138 \mathrm{ng} / \mathrm{dL}$ (n.v. 80 to 180 $\mathrm{ng} / \mathrm{dL}$ ), $\mathrm{T}_{4}=14.1 \mu \mathrm{g} / \mathrm{dL}$ (n.v. 4.5 to $12.5 \mu \mathrm{g} / \mathrm{dL}$ ), $\mathrm{FT}_{4}=2.5 \mathrm{ng} / \mathrm{dL}$ (n.v. 0.8 to $1.8 \mathrm{ng} / \mathrm{dL}$ ), $\mathrm{TSH}<0.05$ $\mathrm{mUI} / \mathrm{L}$ (n.v. 0.3 to $4.2 \mathrm{mU} / \mathrm{L}$ ) and TRAb $=47.8 \%$ (n.v. $<10 \%)$. She underwent a total thyroidectomy with a modified neck dissection.

The final histological diagnosis was a $3.5 \mathrm{~cm}$ papillary thyroid carcinoma with a complete surrounding capsule that was locally penetrated by the tumor cells localized in the right thyroid lobe. The lymph node dissection showed metastatic disease in 4 from 28 operated nodes.

\section{Clinical course}

After total thyroidectomy, the patient received 100 $\mathrm{mCi}$ of ${ }^{131} \mathrm{I}$ for thyroid remnant ablation. Thyroid bed and brain uptake was found in the post-therapy whole body scan (WBS).

She received an accumulated ${ }^{131} \mathrm{I}$ dose of $700 \mathrm{mCi}$ during the following two years. The first post dose 
whole body scan performed after $100 \mathrm{mCi}^{131} \mathrm{I}$ showed uptake in the thyroid bed and in the brain. She then received three more radioiodine doses of $200 \mathrm{mCi}^{131} \mathrm{I}$, all of them showed diffuse uptake in both lungs and also in the brain. Two years after the first evaluation in our hospital, she died from the consequences of multiple metastatic lesions.

Informed consent was obtained from the patient's family to perform these studies.

\section{MATERIALS AND METHODS}

\section{DNA and RNA extraction}

The DNA was extracted from paraffin-embedded tissue from the tumor and the non-tumoral thyroid as well. The procedure was performed according to that previously described by Suárez et al. (10). As control, we used DNAs extracted from peripheral lymphocytes using a QIAmp Kit (Qiagen Inc. reagents and buffer, USA). The RNA was extracted according to the procedure described by Bounacer et al. (5).

\section{RT-PCR method for detecting RET-PTC and TRK oncogenes}

The reverse transcription reaction was performed as previously described by Bounacer et al. (5), using half the volume of RNA extracted from the paraffin-embedded tissue. One fourth of the cDNA was used for a first PCR amplification with outer primers and 1:10 of this PCR product was amplified again with nested primers. The PCR amplifications were performed according to Bounacer et al. (5) for RET-PTC and for TRK as previously described (11). Ten $\mu \mathrm{L}$ of PCR products were electrophoresed in a $2 \%$ agarose gel for control. PCR primer sequences, used in these studies, were those already published for RET-PTC (5) and for TRK (11).

\section{DNA sequence analysis to study the TSHR and RAS genes}

To amplify the region encoded by exon 10 of the TSHR gene (including the three intracellular loops and the cytoplasmatic tail: residues 442-764), we used the same primers and conditions described by Russo et al (12). The oligonucleotide primers and conditions used to amplify the domains including the "critical" codons
(12/13 or 61) of Ha-, Ki- or N-RAS genes were the same as those published by Suárez et al. (13)

Direct sequencing of the amplified DNA fragments was carried out by the dideoxy-nucleotide method (14) with ${ }^{32} \mathrm{P}$-ATP, using the double strand DNA cycle sequencing system Kit (Gibco-BRL, Life Technologies, France) and the same primers as those in the amplification, following the manufacturers conditions.

\section{Transfection studies in 3T3-Vill cells}

\section{Cell culture}

3T3- Vill mouse fibroblasts (15) and transformants were grown in DMEM containing 10\% newborn bovine serum. The test for colony formation in soft agar was performed following the procedure previously described by Michelin et al. (16).

\section{Expression plasmids}

The TSHR cDNA WT or T620I (Clones 1 and 2) were inserted in the Eco RI or Eco RI-XbaI sites of the pECE vector cloning site. The pECE was inserted in the BamHI site of the pSV2-neo plasmid as previously described (17).

\section{DNA transfection}

Subconfluent cells were transfected with $10 \mu \mathrm{g}$ of the TSHR wild type or mutated recombinant expression plasmids, in the presence of the neomycin analogue G418 sulfate $(400 \mu \mathrm{g} / \mathrm{ml})$, as described (17). Four weeks later, the efficacy of transfection was: 1) WT: 21 foci; 2) T620I Clone 1: 25 foci and 3) T620I Clone 2: 18 foci of resistant cells per $\mu \mathrm{g}$ of cDNA.

\section{Cellular cAMP measurements}

Cells in $2 \mathrm{~cm}^{2}$ dishes (Costar Corp. Cambridge, MA, USA) were incubated with fresh Ham's F-12 medium containing $1.5 \% \mathrm{BSA}, 1 \mathrm{mmol} / \mathrm{l}$ isobutylmethylxantine, $20 \mathrm{mmol} / \mathrm{l}$ HEPES ( $\mathrm{pH}$ 7.4) and supplemented with increasing doses of TSH (Thytropar, Armour Pharmaceutical Co., Phoenix, AZ, USA). After 1 h at $37{ }^{\circ} \mathrm{C}$, cellular cAMP was extracted with $95 \%$ ethanol and measured as previously described. The values were corrected for the DNA content of the wells, assessed as previously described (17). Each experimental point was run in duplicate. 


\section{RESULTS}

The genetic analysis of tumoral DNA revealed point mutations in two different genes: 1) the wild type CAA at codon 61 of $N-R A S$ mutated to CAT, replacing glycine by histidine $(\mathrm{G} 61 \mathrm{H})$ (Figure 3 ) and 2 ) the normal GCC sequence at codon 623 of the TSHR gene was replaced by TCC, changing the alanine by serine (A623S) (Figure 4). In the non-tumoral tissue no mutations were found.

\section{A) Mutation in codon 61 form the $\mathrm{N}$-ras gene}

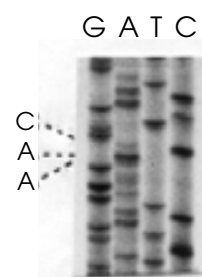

Normal thyroid tissue from the patient (CAA: gen)

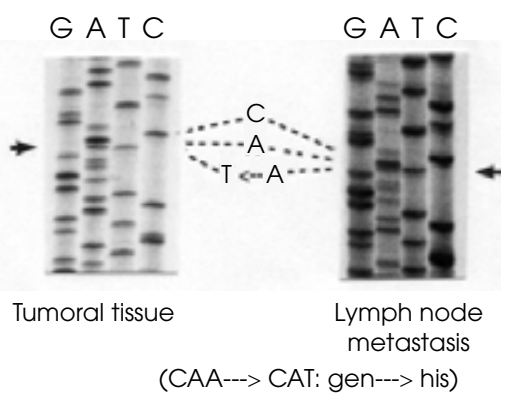

Figure 3. Presence of a point mutation in codon 61 of the $\mathrm{N}$ RAS gene $(\mathrm{G} 61 \mathrm{H})$. Right: Neoplastic tissue and lymph node metastasis (coexistence of CAT and CAA); Left: Normal thyroid tissue from the same patient (Normal).

B) Mutation in codon 623 form the TSHR gene
G A T C

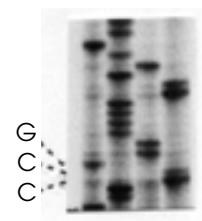

Normal thyroid tissue from the patient (GCC: ala)
G A T C

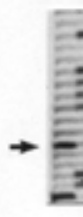

Tumoral tissue
G A T C

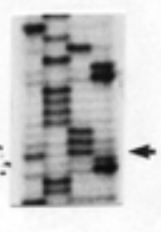

Lymph node metastasis

(GCC---> TCC: ala---> ser)
Figure 4. Presence of a point mutation in codon 623 of the TSH receptor gene (A623S). Right: Tumoral thyroid tissue and lymph node metastasis (coexistence of GCC and TCC); Left: Normal thyroid tissue from the same individual (Normal).

Activation of the cAMP pathway by the transfected plasmids: The A623S transfected cells showed cAMP basal levels that were 4 to 5 fold increased over the values detected in control cells ( $3 \mathrm{~T} 3$ cells transfected with the TSHR-WT cDNA and presenting a normal phenotype). The addition of TSH to the culture medium fur- ther increased the cAMP values (Table 1 ). This increase was higher in the A623S transfected clones.

Table 1. Intracellular cAMP levels in 3T3-Vill cells transfected with the TSHR-WT and the mutant TSHR A623S vectors.

\begin{tabular}{|c|c|c|c|c|}
\hline & \multicolumn{4}{|c|}{ c AMP (pmol/ug DNA) } \\
\hline & & WT & A623S- $\mathrm{Cl}^{1 *}$ & $\mathrm{~A} 623 \mathrm{~S}-\mathrm{Cl}^{2 *}$ \\
\hline \multicolumn{2}{|c|}{ Basal } & $3 \pm 0.3$ & $19 \pm 0.8$ & $12 \pm 0.3$ \\
\hline \multirow[t]{4}{*}{ TSH } & $10 \mathrm{mU} / \mathrm{L}$ & $4.5 \pm 0.2$ & $21 \pm 0.7$ & $19 \pm 0.4$ \\
\hline & $100 \mathrm{mU} / \mathrm{L}$ & $11 \pm 0.3$ & $25 \pm 0.8$ & $22 \pm 0.5$ \\
\hline & $1.000 \mathrm{mU} / \mathrm{L}$ & $22 \pm 0.2$ & $34 \pm 0.7$ & $29 \pm 0.4$ \\
\hline & $10.000 \mathrm{mU} / \mathrm{L}$ & $29 \pm 0.2$ & $45 \pm 0.5$ & $38 \pm 0.9$ \\
\hline
\end{tabular}

The cells were incubated for $1 \mathrm{~h}$ at $37^{\circ} \mathrm{C}$ without (control) or with the indicated doses of TSH in the presence of HEPES ( $20 \mathrm{mmol} / \mathrm{L} ; \mathrm{pH} 7.4), 1.5 \%$ BSA and

isobutylmethylxanthyne (1 mmol/L). CAMP assay was performed as described by Russo et al. (1995). The results are expressed as means \pm SEM

* 3T3-TSHR - A623S - transformed clones 1 or 2

No $T R K$ and $R E T$ rearrangements were found in the tumoral tissue.

\section{DISCUSSION}

In toxic adenomas, several point mutations have been described that activate the TSHR. Activating mutations have been found throughout the transmembrane domain and even in the extracellular domain. TSHR mutations have been found in hyperfunctioning benign thyroid nodules with wide differences between the series that range from $10 \%$ to over $80 \%$ (18-21). Geographical variations, inhomogeneous patient selection, and also differences in the TSHR regions studied may account for such discrepancies.

Recently we presented a case of hyperthyroidism caused by a follicular carcinoma localized in the thyroid gland. The genetic analysis of the tumoral tissue revealed a novel somatic heterozygous mutation in the TSHR gene, responsible for a nonconservative amino acid change in the third intracellular loop of the receptor. I $n$ vitro, this mutation was able to constitutively activate the cAMP cascade (8).

Here, we are presenting a patient with a TSHR activating mutation, but surprisingly the thyroid scintigraphy did not show a "hot" nodule as expected. Very few previous studies, published before our mentioned case report, described the presence of a TSHR activa- 
ting mutation, but in all of them a hyperfunctioning thyroid carcinoma was shown (22-28).

Gsp and TSHR mutations were also found in 6 differentiated carcinomas with constitutively elevated basal cAMP and no further increase following TSH stimulation $(10,12,29)$.

Twenty-three other carcinomas studied by these authors, with low or normal basal cAMP levels and which could be stimulated by TSH, were negative. These data suggested that TSHR mutation may also participate in the tumorigenesis of 'hypofunctioning' thyroid tumours. In fact, sustained elevation of cAMP leads in vivo to transitory growth of normal follicular cells (30).

It can be hypothesized that in nonfunctioning tumors, the TSHR mutation may confer a growth advantage to a cellular clone in which another yet unknown genetic modification had already abrogated a growth-limiting mechanism, which normally downregulates the response to cAMP (e.g. RAS). This could be in accordance with the finding of a simultaneous presence of RAS and gsp or TSHR mutations in 'spontaneous' papillary carcinomas $(12,29)$. Conversely, the presence of RAS mutations in hot nodules may be related to an associated occult tumor or the presence of two cell populations in a single tumor. It may also be consistent with another genetic abnormality that masks the inhibition of cell function induced by RAS mutation.

Another reason for the TSHR activating mutation occurring in a nonfunctioning thyroid nodule may be explained through the idea of cross-signaling. In this patient, two consecutive mutations were observed in the tumor tissue. The one in the TSHR, instead of producing hyperfunction by increasing cell differentiation, as expected through the PKA cascade, has disclosed a totally opposite behavior since the nodule was "cold" in the scintiscan. On the other hand, the second mutation activated the RAS protein, producing a permanent overactivity of the MAPK pathway, probably increasing proliferation, genomic instability and decreasing cell differentiation (31). Under experimental conditions, it was shown that some stages of the MAPK pathway can be stimulated from the PKA stage, by means of the cross-signaling mechanism (3234). Therefore, another hypothesis for the presence of a "cold" hypofunctioning nodule could be this men- tioned mechanism, which may also aggravate the behavior of the papillary thyroid cancer observed in our patient.

Simultaneous alterations of GNAS, RET/PTC, TSHR and RAS were sought in 114 benign and malignant thyroid tumors, but they were found only in 5 cases. This very low frequency of simultaneous alterations indicates that these genes may intervene alternatively in the tumorigenic process and that they are mutually exclusive $(35,36)$.

A number of studies have shown increased aggressiveness of papillary thyroid cancer and follicular thyroid cancer in Graves' disease patients (37-39), and many investigators have strongly suggested that the thyroid-stimulating antibodies cause greater aggressiveness of thyroid malignancy. However, it has recently been suggested that the outcome of Graves' disease patients with papillary thyroid cancer was similar to that of euthyroid patients with papillary thyroid cancer (40).

In conclusion, we describe an activating mutation in codon 623 of the TSHR (A623S). We also found a simultaneous N-RAS mutation $(\mathrm{G} 61 \mathrm{H})$. We hypothesize that the combination of these two mutations might have played an important role in the carcinogenetic process. It is also supposed that the high levels of circulating TRAb might also contribute to further stimulate the mutated TSHR, as judged by the performed transfection studies.

On the other side, the presence of a cross-signaling mechanism might explain the deviation of the TSH receptor cascade to the more proliferative one involving the MAPKinase, giving a more aggressive behavior of this papillary thyroid cancer.

No potencial conflict of interest relevant to this article was reported.

\section{REFERENCES}

1. Lyons J, Landis CA, Harsh G, Vallar L, Grunewald K, Feichtinger $\mathrm{H}$, et al. Two $\mathrm{G}$ protein oncogenes in human endocrine tumors. Science. 1990;249:655-9.

2. Russo D, Arturi F, Schlumberger M, Caillou B, Monier R, Filetti $\mathrm{S}$, et al. Activating mutations of the TSH receptor in differentiated thyroid carcinomas. Oncogene. 1995;11:1907-11.

3. Suárez HG, Du Villard JA, Caillou B, Schlumberger M, Tubiana $M$, Parmentier $C$, et al. Detection of activated ras oncogenes in human thyroid carcinomas. Oncogene. 1988;2:403-6. 
4. Yashimoto K, Iwahana H, Fukuda A, Sano T, Saito G, Itakura $M$. Role of p53 mutations in endocrine tumorigenesis: mutations detection by polymerase chain reaction-single strand conformation polymorphism. Cancer Res. 1992;52:5061-4.

5. Bounacer A, Wicker R, Caillou B, Cailleux AF, Sarasin A, Schlumberger $\mathrm{M}$, et al. High prevalence of activating ret proto-oncogene rearrangements, in thyroid tumors from patients who had received external radiation. Oncogene. 1997; 15:1263-73.

6. Santoro M, Carlomagno F, Hay ID, Herrmann MA, Grieco M, Melillo RM, et al. Ret oncogene activation in human thyroid neoplasms is restricted to the papillary cancer subtype. J Clin Invest. 1992;89:1517-22.

7. Ito T, Seyama T, Mizuno T, Tsuyama N, Hayashi T, Hayashi $Y$, et al. Unique association of p53 mutations with undifferentiated but not with differentiated carcinomas of the thyroid gland. Cancer Res. 1992;52:1369-71.

8. Niepomniszcze H, Suárez H, Pitoia F, Pignatta A, Danilowicz $\mathrm{K}$, Manavela $\mathrm{M}$, et al. Follicular carcinoma presenting as autonomous functioning thyroid nodule and containing an activating mutation of the TSH receptor (T620I) and a mutation of the Ki-RAS (G12C) genes. Thyroid. 2006;16:497-503.

9. Russo D, Tumino S, Arturi F, Vigneri P, Rasso G, Pontecorvi A, et al. Detection of an activating mutation of the thyrotropin receptor in a case of an autonomously hyperfunctioning thyroid insular carcinoma. J Clin Endocrinol Metab. 1997;82:735-8.

10. Suarez HG, du Villard JA, Caillou B, Schlumberger M, Parmentier C, Monier R. Gsp mutations in human thyroid tumours. Oncogene. 1991;6:677-9.

11. Bounacer $A$, Schlumberger $M$, Wicker $R$, Du-Villard JA, Caillou B, SaRasin A, et al. Search for NTRK1 proto-oncogene rearrangements in human thyroid tumours originated after therapeutic radiation. Br J Cancer. 2000;82:308-14.

12. Russo D, Arturi F, Schlumberger M, Caillou B, Monier R, Filetti $\mathrm{S}$, et al. Activating mutations of the TSH receptor in differentiated thyroid carcinomas. Oncogene. 1995;11:1907-11.

13. Suárez HG, du Villard JA, Severino M, Caillou B, Schlumberger M, Tubiana M, et al. Presence of mutations in all three Ras genes in human thyroid tumors. Oncogene. 1990;5:565-70.

14. Sanger F, Nicklen S, Coulson AR. DNA sequencing with chain-terminating inhibitors. Proc Natl Acad Sci U S A. 1977;74:5463-7.

15. Suárez HG, du Villard JA, Caillou B, Schlumberger M, Tubiana $M$, Parmentier $C$, et al. Detection of activated Ras oncogenes in human thyroid carcinomas. Oncogene. 1988;2:403-6.

16. Michelin S, Varlet I, Martinerie C, Perbal B, SaRasin A, Suarez HG. V-myb transformation of xeroderma pigmentosum human fibroblasts: overexpression of the c-Ha-Ras oncogene in the transformed cells. Exp Cell Res. 1991;196:314-22.

17. du Villard JA, Wicker R, Crespo P, Russo D, Filetti S, Gutkind JS, et al. Role of the CAMP and MAPK pathways in the transformation of mouse 3T3 fibroblasts by a TSHR gene constitutively activated by point mutation. Oncogene. 2000;19: 4896-905.

18. Russo D, Arturi F, Wicker R, Chazenbalk GD, Schlumberger $M$, duVillard JA, et al. Genetic alterations in thyroid hyperfunctioning adenomas. J Clin Endocrinol Metab. 1995;80:1347-51.

19. Takeshita A, Nagayama Y, Yokoyama N, Ishikawa N, Ito K, Yamashita T, et al. Rarity of oncogenic mutations in the thyrotropin receptor of autonomously functioning thyroid nodules in Japan. J Clin Endocrinol Metab. 1995;80:2607-11.
20. Parma J, Duprez L, Van Sande J, Hermans J, Rocmans P, Van Vliet $\mathrm{G}$, et al. Diversity and prevalence of somatic mutations in the thyrotropin receptor and Gs alpha genes as a cause of toxic thyroid adenomas. J Clin Endocrinol Metab. 1997;82:2695-701.

21. Trulzsch B, Krohn K, Wonerow P, Chey S, Hozapfel HP, Ackermann $F$, et al. Detection of thyroid-stimulating hormone receptor and Gsalpha mutations: in 75 toxic thyroid nodules by denaturing gradient gel electrophoresis. J Mol Med. 2001;78:684-91.

22. Spambalg D, Sharifi N, Elisei R, Gross JL, Medeiros-Neto G, Fagin JA. Structural studies of the thyrotropin receptor and Gs alpha in human thyroid cancers: low prevalence of mutations predicts infrequent involvement in malignant transformation. J Clin Endocrinol Metab. 1996;81:3898-901.

23. Russo D, Tumino S, Arturi F, Vigneri P, Grasso G, Pontecorvi $A$, et al. Detection of an activating mutation of the thyrotropin receptor in a case of an autonomously hyperfunctioning thyroid insular carcinoma. J Clin Endocrinol Metab. 1997; 82:735-8.

24. Russo D, Wong MG, Costante G, Chiefari E, Treseler PA, Arturi F, et al. A Val 677 activating mutation of the thyrotropin receptor in a Hurthle cell thyroid carcinoma associated with thyrotoxicosis. Thyroid. 1999;9:13-7.

25. Camacho P, Gordon D, Chiefari E, Yong S, DeJong S, Pitale S, et al. A Phe 486 thyrotropin receptor mutation in an autonomously functioning follicular carcinoma that was causing hyperthyroidism. Thyroid. 2000;10:1009-12.

26. Mircescu H, Parma J, Huot C, Deal C, Oligny LL, Vassart G, et al. Hyperfunctioning malignant thyroid nodule in an 11-yearold girl: pathologic and molecular studies. J Pediatr. 2000;137:585-7.

27. Fuhrer D, Tannapfel A, Sabri O, Lamesch P, Paschke R. Two somatic TSH receptor mutations in a patient with toxic metastastising follicular thyroid carcinoma and non-functional lung metastases. Endocr Relat Cancer. 2003;10:591-600.

28. Gozu H, Avsar M, Bircan R, Sahin S, Ahiskanali R, Gulluoglu B, et al. Does a Leu 512 Arg Thyrotropin receptor mutation cause an autonomously functioning papillary carcinoma? Thyroid. 2004;14:975-80.

29. Saïd S, Schlumberger M, Suarez HG. Oncogenes and antioncogenes in human epithelial thyroid tumors. J Endocrinol Invest. 1994;34:371-9.

30. Wynford-Thomas D. Origine et progression des tumeurs aepitheliales: vers les mecanismes cellulaires et moleculaires. Med Sci (Paris). 1993;9:66-75.

31. Figge J. Molecular pathogenesis of thyroid cancer. In: Wartofsky LMD, editor. Thyroid cancer: a comprehensive guide to clinical management. New Jersey: Humana Press; 2000.

32. Dumont JE, Pécasse F, Maenhaut C. Crosstalk and specificity in signalling. Are we crosstalking ourselves into general confusion? Cell Signal. 2001;13:457-63.

33. Dumont JE, Dremier S, Pirson I, Maenhaut C. Cross signaling, cell specificity, and physiology American Journal of Physiology. J Cell Physiol. 2002;283:C2-28.

34. García Jimenez C, Santisteban P. TSH Signaling and Cancer. Arq Bras Endocrinol Metab. 2007;51:654-71.

35. Suarez HG. Genetic alterations in human epithelial thyroid tumours. Clin Endocrinol (Oxf). 1998;48:531-46.

36. Kimura ET, Nikiforova MN, Zhu Z, Knauf JA, Nikiforov $Y E$, Fagin JA. High prevalence of BRAF mutations in thyroid can- 
cer: genetic evidence for constitutive activation of the RET/ PTC-RAS-BRAF signaling pathway in papillary thyroid carcinoma. Cancer Res. 2003;63:1454-7.

37. Mazzaferri EL. Thyroid cancer and Graves' disease. J Clin Endocrinol Metab. 1990;70:826-9.

38. Pellegriti G, Belfiore A, Giuffrida D, Lupo L, Vigneri R. Outcome of differentiated thyroid cancer in Graves' patients. J Clin Endocrinol Metab. 1998;83:2805-9.

39. Katz SB, Garcia AJ, Niepomniszcze H. Development of Graves' disease nine years after total thyroidectomy due to follicular carcinoma of the thyroid. Thyroid. 1997;7:909-11.
40. Yano $Y$, Shibuya H, Kitagawa W, Nagahama M, Sugino $K$, Ito $\mathrm{K}$, et al. Recent outcome of Graves' disease patients with papillary thyroid cancer. Eur J Endocrinol. 2007;157:325-9.

Correspondence to:

Hugo Niepomniszcze

Division of Endocrinology, Hospital de Clínicas, University of Buenos Aires

Av. Córdoba 2351, 5to piso

Buenos Aires Argentina

E-mail: hniepom@elsitio.net 